\begin{tabular}{cc}
\hline JPPIPA, Vol.2 No.2 2017 \\
Juttp://journal.unesa.ac.id/index.php/jppipa
\end{tabular}

\title{
PENINGKATAN KETERAMPILAN PROSES SAINS SISWA MELALUI MODEL EXPERIENTIAL LEARNING PADA MATERI PENCEMARAN LINGKUNGAN
}

Oleh:

Ageng Kastawaningtyas ${ }^{1}$, Martini $^{2}$

1,2Jurusan IPA, Fakultas MIPA, Universitas Negeri Surabaya, Surabaya 60231, Indonesia.

\begin{abstract}
Abstrak
Penelitian ini dilatarbelakangi oleh hasil pra penelitian yang dilakukan di kelas VII-I SMPN 21 Surabaya yang memiliki keterampilan proses sains yang belum maksimal. Penelitian bertujuan untuk meningkatkan keterampilan proses sains melalaui experiential learning, yaitu model pembelajaran yang memanfaatkan pengalaman baru dan reaksi siswa terhadap pengalamannya untuk membangun pemahaman dan transfer pengetahuan, keterampilan, serta sikap dengan sintaks cocrete experince, reflective observation, abstract conceptualizatin, dan active experimentation. Jenis penelitian yang digunakan yakni pre experimental design dengan rancangan penelitian one group pretest posttest design. Subjek dalam penelitian ini adalah siswa kelas VII-I SMPN 21 Surabaya yang berjumlah 37 siswa. Hasil penelitian menunjukkan bahwa keterampilan proses sains siswa meningkat setelah diterapkan model experiential learning, dengan persentase rata-rata ketuntasan pretest keterampilan proses sains siswa adalah 5\% dan meningkat pada posttest dengan persentase sebesar $92 \%$. N-Gain Score untuk keterampilan proses sains sebesar 0,72 dengan kategori tinggi. Tiga aspek mendapatkan kategori peningkatan tinggi pada merumuskan masalah, menginterpretasi data, dan membuat kesimpulan, sedangkan dua aspek mendapatkan peningkatan kategori sedang yaitu merumuskan hipotesis dan mengidentifikasi variabel.
\end{abstract}

Kata Kunci : Keterampilan proses sains, experiential learning.

\section{Abstract}

The research is motivated by the results of pre-research conducted in class VII-I SMPN 21 Surabaya who have the skills of the science process that has not been maximized. The research aims to improve the science process skills through experiential learning, which is a model of learning that utilizes new experiences and reactions of students to their experiences to build understanding and transfer of knowledge, skills and attitudes with the syntax of cocrete experince, reflective observation, abstract conceptualizatin, and active experimentation. The type of research used was pre experimental design with one group pretest posttest design research. Subjects in this study were students of class VII-I SMPN 21 Surabaya, amounting to 37 students. The results showed that students' science process skills increased after the experiential learning model was applied, with the average percentage of completeness pretest of science process skills of students was $5 \%$ and increased in posttest with a percentage of $92 \%$. $N$-Gain Score for science process skills of 0.72 with high category. Three aspects get high improvement categories on formulating problems, interpreting data, and making conclusions, while the two aspects get a moderate category improvement that is formulating hypotheses and identifying variables.

Keywords: Science process skills, experiential learning.

(C) 2017 Universitas Negeri Surabaya

${ }^{2}$ Alamat Korespondensi:

Jurusan IPA, Fakultas MIPA, Universitas

p-ISSN: $2527-7537$

Negeri Surabaya, Surabaya 60231, Indonesia

e-ISSN: 2549-2209

Email:martni@unesa.ac.id 


\section{PENDAHULUAN}

Ilmu Pengetahuan Alam (IPA) atau sains merupakan salah satu cabang ilmu yang pengkajiannya berfokus pada alam dan prosesproses yang ada di dalamnya. IPA atau sains berasal dari kata "natural science". Natural memiliki arti alamiah dan berhubungan dengan alam, sedangkan science artinya ilmu pengetahuan. Artinya, sains dipandang sebagai ilmu pengetahuan yang mempelajari tentang alam atau yang mempelajari peristiwa-peristiwa yang terjadi di alam. (Bundu, 2006). Perkembangannya ditandai oleh adanya kumpulan fakta, metode ilmiah dan sikap ilmiah. Berdasarkan definisi tersebut, IPA pada hakikatnya adalah ilmu untuk mencari tahu, memahami alam semesta secara sistematik, serta mengembangkan pemahaman dan penerapan konsep untuk dijadikan sebagai suatu produk, sehingga pembelajaran IPA bisa menjadi sarana bagi siswa untuk mempelajari diri sendiri dan lingkungannya, serta dapat mengembangkan pengetahuan yang diperoleh untuk kesejahteraan umat manusia.

Aktivitas yang berkaitan dengan IPA tidak terlepas di dalam kehidupan sehari-hari, sehingga pembelajaran IPA adalah pembelajaran yang mempunyai hubungan erat dengan pengalaman sesungguhnya. Siswa didorong untuk menemukan dan mengkonstruksi sendiri pengetahuan yang ada di pikirannya melalui penggunaan keterampilan proses sains dan sikap ilmiah, sehingga siswa bukan hanya sekedar pengguna atau penghafal pengetahuan, melainkan sebagai penemu dan pemilik ilmu (Widodo dkk, 2014). Siswa perlu untuk bekerja dan melibatkan diri secara langsung dalam proses menemukan informasi agar siswa benar-benar memahami dan dapat menerapkan pengetahuan yang ia dapatkan. Dalam Peraturan Pemerintah Republik Indonesia Nomor 32 Tahun 2013 tentang Perubahan Atas Peraturan Pemerintah Nomor 19 Tahun 2005 tentang Standar Nasional Pendidikan, pasal 19 ayat 1 , proses pembelajaran pada satuan pendidikan diselenggarakan secara interaktif, inspiratif, menyenangkan, menantang, memotivasi siswa untuk berpartisipasi aktif, serta memberikan ruang yang cukup bagi prakarsa, kreativitas, dan kemandirian sesuai dengan bakat, minat, dan perkembangan fisik serta psikologis siswa. Sesuai dengan peraturan pemerintah tersebut, pembelajaran IPA harus dilaksanakan secara aktif. Siswa harus terlibat aktif dalam pembelajaran sehingga dapat mengkonstruksi sendiri pengetahuan yang diperolehnya. Pengetahuan yang dikonstruksi sendiri oleh siswa menjadikan pengetahuan tersebut lebih bermakna dan tidak mudah terlupakan.

Berdasarkan hasil wawancara yang dilakukan oleh peneliti kepada salah satu guru IPA SMPN 21 Surabaya diperoleh bahwa kegiatan pembelajaran di sekolah masih jarang disertai dengan kegiatan praktikum. Jenis praktikum yang dilakukan yaitu pengamatan sedangkan kegiatan eksperimen jarang dilakukan. Dengan kata lain, siswa jarang mengalami pengalaman belajar langsung, sehingga keterampilan proses sains pada diri siswa tidak berkembang. Hal ini ditunjukkan dari data pra penelitian bahwa $100 \%$ siswa belum mampu untuk merumuskan masalah, merumuskan hipotesis, mengidentifikasi variabel, menganalisis data, dan membuat kesimpulan. Hal ini mengakibatkan pemahaman siswa terhadap suatu materi pelajaran menjadi kurang maksimal yang dapat berpengaruh pada ketuntasan belajar siswa. Berdasarkan data tersebut, maka diperlukan suatu upaya untuk melatihkan keterampilan proses sains siswa sehingga meningkatkan hasil belajar siswa.

Salah satu faktor yang mempengaruhi keberhasilan dalam meningkatkan keterampilan proses sains adalah model pembelajaran yang digunakan guru. Keterampilan proses sains dapat dilatihkan dengan cara siswa memperoleh pengalaman langsung selama proses pembelajaran (Widodo dkk, 2014). Pembelajaran berbasis pengalaman (Experiential Learning) adalah pembelajaran yang mengaktifkan siswa dalam proses belajar dari pengalaman yang menekankan pada hubungan yang harmonis antara belajar, bekerja dan aktivitas belajar lainnya dalam menciptakan atau menemukan pengetahuan yang dicari. Model Experiential Learning ini memiliki tahap-tahap yang sesuai untuk dilaksanakan pada pembelajaran IPA yaitu, 1) tahap concrete experience (pengalaman langsung); 2) tahap reflective observation (merefleksikan observasi); 3) abstrak conceptualization (konsep yang abstrak); dan 4) active experimentation (eksperimentasi aktif) (Kolb, 2014). Kelebihan dari model Experiential Learning (Sharlanova et al, 2004) yaitu membantu siswa menyadari kemampuan diri mereka sendiri, membantu dalam pengembangan proyek kerja kelompok dan memutuskan bagaimana teknologi informasi dan komunikasi dapat membantu proses pembelajaran, serta menyediakan koneksi yang efektif antara teori dan praktek. Siswa diajak untuk memandang secara kritis kejadian dalam kehidupan sehari-hari, kemudian melakukan penelitian (experiment) sederhana untuk mengetahui kejadian yang sebenarnya. Pada tahap akhir siswa menarik kesimpulan bersama. Kesimpulan ini sebagai salah satu pemahaman yang dicapai oleh siswa.

Implementasi dari pembelajaran di atas sangat didukung dengan hasil angket pra penelitian yang disebarkan pada 30 siswa kelas VII-I SMPN 21 Surabaya menyatakan bahwa $100 \%$ siswa senang dan tertarik dengan kegiatan pengamatan dan praktikum, karena dengan kegiatan tersebut siswa dapat mengetahui hal-hal baru dengan melakukan praktik langsung berdasarkan materi yang diperoleh dan 97\% siswa menyatakan lebih memahami materi yang diajarkan melalui kegiatan 46 
praktikum. Sehingga, dengan adanya hasil tersebut diharapkan pembelajaaran IPA di sekolah berorientasi pada keterampilan proses sains. Oleh karena itu, guru perlu menerapkan model Experiential learning dalam pembelajaran yang dikemas menggunakan percobaan ilmiah yang dapat melibatkan siswa secara langsung dalam proses pembelajaran sehingga keterampilan proses sains pada siswa dapat terlatih.

Hal tersebut didukung oleh penelitian Sholehah (2013) menyatakan bahwa kemampuan kerja ilmiah siswa kelas VIII selama mengikuti pelajaran fisika menggunakan model pembelajaran Experiential Learning termasuk kategori baik, dengan persentase sebesar $81,34 \%$. Selain itu, Retnosari (2015) dalam penelitiannya menyatakan bahwa keterampilan proses sains siswa setelah diterapkannya model Experiential Learning pada materi perpindahan kalor mengalami peningkatan dengan kategori "Tinggi”" sebanyak 68,42\%. Hasil penelitan-penelitian tersebut menyatakan penerapan model Experiential Learning menjadikan keterampilan proses sains siswa meningkat.

Berdasarkan berbagai hal yang telah diuraikan, maka muncul sebuah pertanyaan penelitian yaitu "Bagaimana peningkatan keterampilan proses sains siswa kelas VII SMP setelah diterapkan model pembelajaran experiential learning pada materi pencemaran lingkungan?". Oleh karena itu, penelitian ini bertujuan untuk mendeskripsikan peningkatan keterampilan proses sains siswa setalah diterapkan model pembelajaran experiential learning pada materi pencemaran lingkungan di kelas VII SMPN Surabaya. Penelitian ini diharapkan dapat memberikan kontribusi untuk meningkatkan kualitas proses belajar mengajar di sekolah, serta dapat meningkatkan dan mengembangkan keterampilan proses sains siswa di SMPN 21 Surabaya.

\section{METODE}

Jenis penelitian yang digunakan dalam penelitian ini yaitu jenis pre eksperimental design karena tidak ada karakteristik yang disamakan dan tidak ada variabel yang dikontrol (Sukmadinata, 2010). Rancangan penelitian yang digunakan yaitu "One Group Pre-test Post-test Design" yaitu penelitian yang dilakukan pada satu kelompok saja tanpa kelompok pembanding (Sugiyono, 2012)
Penelitian ini diawali dengan pemberian pretest. Penelitian ini dilakukan di SMPN 21 Surabaya, Jawa Timur, yang dilaksanakan pada Semester Genap Tahun Ajaran 2016/2017. Subjek dalam penelitian ini adalah siswa Kelas VII-I SMPN 21 Surabaya yang berjumlah 37 siswa.

Teknik pengumpulan data yang digunakan dalam penelitian ini yaitu tes. Tes dilakukan dua kali yaitu sebelum (pretest) dan sesudah penerapan model pembelajaran experiential learning (posttest), yang digunakan untuk mengetahui ada tidaknya peningkatan keterampilan proses sains siswa setelah diterapkan model pembelajaran experiential learning pada materi pencemaran lingkungan. Instrumen yang digunakan dalam penelitian ini yaitu soal yang berorientasi keterampilan proses sains, setiap butir soal mewakili indikator keterampilan proses sains yang dilatihkan. Soal pretest dan posttest berisi soal yang berbeda namun indikator dan tingkat kesulitannya sama.

Data yang diperoleh tersebut dianalisis secara deskriptif kuantitatif dengan mendeskripsikan ketuntasan keterampilan proses sains tiap siswa serta ketercapaian keterampilan proses sains tiap aspek. Hasil nilai pretest dan postest yang diperoleh dilakukan uji normalitas untuk pengujian data normal, uji-t berpasangan untuk pengujian ada tidaknya signifikansi perbedaan hasil pretest dan posttest, dan uji gain-score ternormalisasi untuk pengujian peningkatan keterampilan proses sains siswa. Setelah didapatkan bahwa data terdistribusi normal dan terdapat perbedaan siginifikan antara hasil pretest dan posttest, barulah dilakukan uji gain score untuk mengetahui seberapa besar peningkatan keterampilan proses sains siswa.

Untuk mengetahui kriteria peningkatan KPS siswa maka dilakukan analisis gain ternormalisasi $<$ g $>$ yang dinyatakan dalam rumus matematis sebagai berikut:

$$
<\mathrm{g}>=\frac{\%(S f)-\%(S i)}{100-\%(S i)}
$$

Keterangan:

$$
\begin{array}{ll}
<\mathrm{g}> & =\text { skor gain ternormalisasi } \\
\mathrm{Si} & =\text { skor pre-test } \\
\mathrm{Sf} & =\text { skor post-test }
\end{array}
$$

Menurut Hake (1998:2) pengelompokan hasil skor gain ternormalisasi dibagi ke dalam tiga kategori yaitu sebagai berikut:

Tabel 1. Kriteria Gain Ternormalisasi

\begin{tabular}{cc}
\hline Persentase & Klasifikasi \\
\hline $0,0<(<\mathrm{g}>) \leq 0,3$ & Rendah \\
\hline $0,3<(<\mathrm{g}>) \leq 0,7$ & Sedang \\
\hline $0,7<(<\mathrm{g}>) \leq 1,0$ & Tinggi
\end{tabular}


Ketuntasan KPS siswa dihitung dengan menggunakan rumus:

$$
\text { Nilai KPS }=\frac{\text { Skor yang dicapai }}{\text { Skor Maksimum }} \times 100
$$

Adapun kriteria ketuntasan minimal untuk keterampilan proses siswa dalam mata pelajaran IPA di SMPN 21 Surabaya adalah 72 dengan kategori (C).

Tabel 2. Kriteria Ketuntasan Keterampilan Proses Sains

\begin{tabular}{cc}
\hline Nilai & Kategori \\
\hline$>90-100$ & Sangat Baik (A) \\
\hline$>81-90$ & Baik (B) \\
\hline$\geq 72-81$ & Cukup (C) \\
\hline$<72$ & Kurang (D)
\end{tabular}

\section{HASIL DAN PEMBAHASAN}

Hasil keterampilan proses sains siswa dapat dianalisis dengan menggunakan nilai pretest dan posttest siswa. Hasil pretest dan posttest diperoleh bahwa dari 37 siswa yang mengikuti pretest tentang keterampilan proses sains siswa diperoleh hasil bahwa 35 siswa dinyatakan tidak tuntas dan 2 siswa yang tuntas. Hal ini didasarkan pada ketuntasan minimal aspek keterampilan SMPN 21 Surabaya yaitu 72, yang interval kriterianya telah ditentukan berdasarkan Panduan Penilaian SMP 2016.. Siswa dinyatakan tuntas jika mendapat nilai lebih dari atau sama dengan 72, jika kurang dari 72 maka siswa dinyatakan tidak tuntas. Hasil berbeda didapatkan dari nilai posttest siswa yaitu hanya $8 \%$ siswa, yaitu 3 siswa yang dinyatakan tidak tuntas dan $92 \%$ siswa, yaitu 34 siswa dinyatakan tuntas. Perbandingan persentase ketuntasan hasil pre-test dan post-test KPS siswa dapat dilihat pada grafik berikut ini:

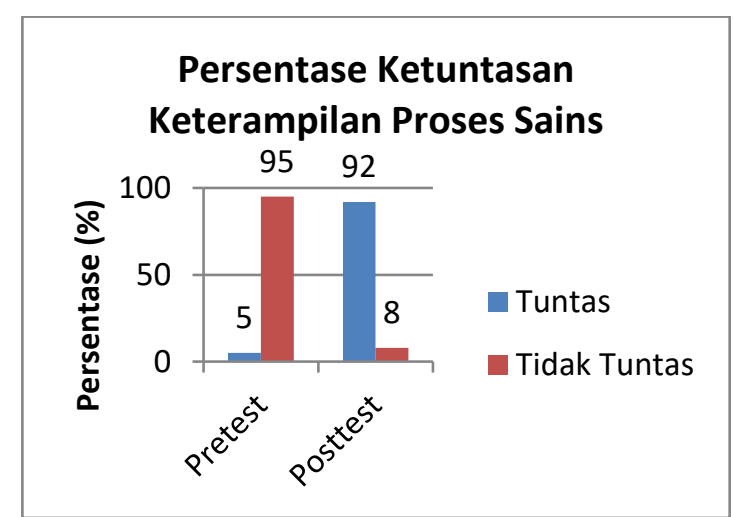

Gambar 1. Persentase Ketuntasan Keterampilan Proses Sains Siswa

Keterampilan proses siswa sains merupakan salah rumusan masalah terpenting yang dikaji dalam penelitian ini. Dalam penelitian ini hanya lima keterampilan proses sains yang dilatihkan, yaitu merumuskan masalah, merumuskan hipotesis, mengidentifikasi variabel, menginterpretasi data, dan menyimpulkan data melalui model pembelajaran Experiential Learning. Hasil pretest menunjukkan bahwa 95\% siswa tidak tuntas karena skor yang mereka peroleh dibawah standar minimal yang telah ditentuan SMPN 21 Surabaya yaitu 72, yang interval kriterianya telah ditentukan berdasarkan Panduan Penilaian SMP 2016. Dari pernyataan siswa kelas VII-I SMPN 22 Surabaya yang didapatkan guru, sebenarnya mereka bukannya tidak pernah melakukan keterampilan proses sains namun mereka hanya tidak tahu dan kurang memahami bahwa yang mereka lakukan adalah bagian dari keterampilan proses sains.

Keterampilan proses sains melibatkan keterampilan-keterampilan kognitif atau intelektual, manual, dan sosial. Keterampilan kognitif atau intelektual dengan melakukan keterampilan proses siswa menggunakan pikirannya, keterampilan manual terlibat dalam penggunaan alat dan bahan, pengukuran, penyusunan atau perakitan alat, keterampilan sosial dimaksudkan bahwa dengan keterampilan proses siswa berinteraksi dengan sesamanya dalam melaksanakan kegiatan belajar mengajar (Rustaman, 2005). Hasil keterampilan proses sains siswa memiliki perbedaan yang signifikan antara sebelum dan sesudah diterapkannya model Experiential Learning pada materi pencemaran lingkungan. Perbedaan tersebut dapat diketahui melalui perhitungan uji-t berpasangan dengan nilai thitung $(13,98)>$ ttabel $(2,247)$. Hal ini menunjukkan bahwa ada hubungan antara model Experiential Learning dengan keterampilan proses sains. 
Besar peningkatan ketercapaian KPS siswa dapat diketahui dengan menghitung nilai N-Gain. Hasil perhitungan yang didapat dengan menggunakan $\mathrm{N}$-Gain kemudian dikelompokkan menjadi 3 kategori. Rata-rata peningkatan hasil pre-test dan post-test siswa tentang KPS yaitu sebesar 0,72 dengan kategori tinggi. Hal tersebut dapat diartikan bahwa penerapan model
Experiential Learning pada materi pencemaran lingkungan dapat meningkatkan keterampilan proses sains siswa. Untuk memperjelas uraian di atas, disajikan persentase peningkatan hasil posttest terhadap pretest siswa kelas VII-I pada tabel 3 berikut ini.

Tabel 3. Uji N-Gain Hasil Pretest dan Postest

\begin{tabular}{ccccc}
\hline \multirow{2}{*}{ Sampel } & $\begin{array}{c}\text { Persentase } \\
\text { Peningkatan }\end{array}$ & Kategori Peningkatan & Jumlah Siswa & $\begin{array}{c}\text { Persentase Jumlah Siswa } \\
(\%)\end{array}$ \\
\hline \multirow{2}{*}{ Kelas } & $(\mathrm{g})<0,3$ & Rendah & 2 & 5,40 \\
\cline { 2 - 5 } VII-I & $0,3 \leq(\mathrm{g})<0,7$ & Sedang & 6 & 16,22 \\
\cline { 2 - 5 } & $(\mathrm{g})>0,7$ & Tinggi & 29 & 78,38 \\
\hline \multicolumn{2}{r}{ Jumlah } & & 37 & 100 \\
\hline
\end{tabular}

Berdasarkan Tabel 3, peningkatan keterampilan proses sains dengan gain score dapat ditunjukkan pada diagram sebagai berikut.

\section{Diagram Peningkatan Keterampilan Proses Sains}

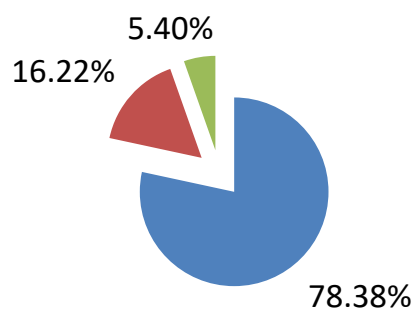

Gambar 2. Persentase peningkatan keterampilan proses sains dengan $\mathrm{N}$-Gain

Peningkatan keterampilan proses sains dihitung dengan analisis uji N-gain. Berdasarkan Tabel 3 setelah diterapkan model Experiential Learning pada materi pencemaran lingkungan dengan menggunakan perhitungan gain score sebanyak $78,38 \%$ siswa mengalami peningkatan keterampilan proses sains dengan kriteria tinggi. Sebanyak $16,22 \%$ siswa mengalami peningkatan keterampilan proses sins dengan kategori sedang dan sebanyak 5,40\% siswa mengalami peningkatan keterampilan prses sains dengan kategori rendah. Dalam model Experiential Learning siswa akan berperan sebagai peneliti yang menemukan sendiri informasi-informasi penting untuk menyelesaikan permasalahan melalui sebuah penyelidikan ilmiah sebagai bentuk dari pengalaman belajar langsung. Experiential learning merujuk pada pembelajaran melalui tindakan, belajar dengan melakukan sesuatu, belajar melalui pengalaman, dan belajar melalui penemuan dan eksplorasi (Northern Illinois University, 2011).

Meningkatnya keterampilan proses sains siswa dipengarui pula oleh peningkatan nilai rata-rat setiap indikator keterampilan proses sains. Hasil peningkatan keterampilan proses sains untuk setiap aspek keterampilan dapat dilihat pada Tabel 4.

Tabel 4. Peningkatan Tiap Aspek Keterampilan Proses Sains

\begin{tabular}{|c|c|c|c|c|}
\hline \multirow{2}{*}{$\begin{array}{c}\text { Aspek Keterampilan } \\
\text { Proses Sains }\end{array}$} & \multicolumn{2}{|c|}{ Persentase Ketercapaian (\%) } & \multirow[b]{2}{*}{$\langle\mathrm{g}\rangle$} & \multirow{2}{*}{ Kategori } \\
\hline & Pre-test & Post-test & & \\
\hline Merumuskan masalah & 1,84 & 3,34 & 0,70 & Tinggi \\
\hline $\begin{array}{l}\text { Merumuskan } \\
\text { hipotesis }\end{array}$ & 2,58 & 3,37 & 0,56 & Sedang \\
\hline $\begin{array}{l}\text { Mengidentifikasi } \\
\text { variabel }\end{array}$ & 1,71 & 3,26 & 0,68 & Sedang \\
\hline engintepretasi data & 2,11 & 3,50 & 0,74 & Tinggi \\
\hline Menyimpulkan & 2,08 & 3,55 & 0,77 & Tinggi \\
\hline
\end{tabular}

Berdasarkan Tabel 4, diketahui keterampilan proses sains yang dilatihkan diperoleh hasil secara keseluruhan mengalami peningkatan untuk setiap indikatornya. Rata-rata dari kelima indikator keterampilan proses sains termasuk dalam kategori tinggi.

Rata-rata setiap aspek keterampilan proses sains yang telah diujikan pada siswa berdasarkan 
hasil pretest dan posttest dapat disajikan seperti pada Gambar 3. berikut.

\section{Diagram Peningkatan Keterampilan Proses Sains Tiap Indikator}

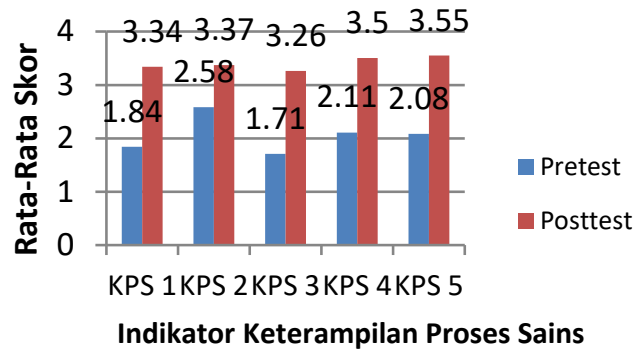

Gambar 3. Diagram Peningkatan Skor Tiap Indikator Keterampilan Proses Sains

Keterangan:

KPS 1 : Merumuskan Masalah

KPS 2 : Merumuskan Hipotesis

KPS 3 : Mengidentifikasi variabel

KPS 4 : Menginterpretasi data

KPS 5 : Menyimpulkan

Berdasarkan Tabel 4 dan Gambar 3, setiap aspek keterampilan proses sains yang dilatihkan mengalami peningkatan. Keterampilan merumuskan hipotesis dan mengidentifikasi variabel mengalami peningkatan sebesar 0,56 dan 0,68 dengan kategori sedang, sementara keterampilan merumuskan masalah, menginterpretasi data, dan membuat kesimpulan sebesar 0,70; 0,74; dan 0,77 dengan kategori tinggi.

Berdasarkan Tabel 3 hasil peningkatan setiap aspek keterampilan proses sains yang diamati meliputi keterampilan merumuskan masalah, membuat hipotesis, mengidentifikasi variabel percobaan, menginterpretasi data, dan menari kesimpulan. Keterampilan merumuskan masaah mengalami peningkatan dari pretest 1,84 menjadi 3,34 setelah diterapkan model Experiential Learning pada materi pencemaran lingkungan. Keterampilan merumuskan masalah mengalami peningkatan dengan kategori tinggi dengan gain score sebesar 0,70. Selama pembelajaran dengan model Experiential Learning siswa dilatihan dengan melakukan kegiatan eksperimen yang dibantu oleh Lembar Kerja Siswa (LKS) yang berorientasi pada keterampilan proses sains, dimana sebelum siswa melakukan percobaan, siswa diberi kesempatan untuk mengungkapkan pengalaman pribadinya tentang materi terkait, yaitu materi pencemaran lingkungan. Proses mengungkapkan pengalaman siswa ini terdapat pada fase concrete experience. Keterampilan merumuskan masalah dilatihkan pada fase reflective observation. Sesudah siswa mengungkapkan pengalamannya yang didukung dengan kegiatan awal berupa demonstrasi, langkah selanjutnya yaitu dari pengalaman siswa tersebut nantinya akan ditemukan beberapa masalah, dan dari masalah-masalah tersebut siswa menentukan rumusan masalahnya. Hal ini sesuai dengan pendapat Suparman (2001), belajar yang berbentuk respons terhadap kondisi yang terbatas akan ditransfer kepada kondisi lain yang terbatas pula. Keterampilan merumuskan masalah juga dilatihkan melalui Lembar Kegiatan Siswa (LKS). Dengan bimbingan guru, siswa merumuskan masalah berdasarkan ilustrasi yang tedapat pada LKS. Kemudian di akhir pembelajaran guru mengulang kembali bagaimana cara merumuskan masalah yang benar.

Pada keterampilan proses membuat hipotesis siswa diharapkan mampu membuat dugaan sementara hasil percobaan sesuai rumusan masalah yang diajukan. Siswa harus membuat dugaan yang logis dan dapat diuji melalui suatu percobaan. Keterampilan membuat hipotesis mengalami peningkatan dari pretest sebesar 2,58 menjadi 3,37 setelah diterapkan model Experiential Learning pada pembelajaran pencemaran lingungan. Keterampilan membuat hipotesis ini menglami peningkatan gain score sebesar 0,56 dengan kategori sedang. Keterampilan membuat hiotesis ini juga dilatihkan melalui kegiatan eksperimen yang dibantu LKS pada tahap abstract conceptualization. Setelah siswa merumuskan masalah, siswa dibimbing untuk menemukan suatu dugaan yang melibatkan dua variabel percobaan yang saling berhubungan. Hipotesis yang telah dibuat nantinya akan dibuktikan melalui kegiatan praktikum pada fase active experimentatin. Hal ini sesuai dengan Sharlanova et al (2004) menyatakan bahwa belajar melibatkan lebih banyak logika dan gagasan dari pada perasaan memahami masalah atau situasi. Hal ini adalah suatu tipe untuk mengikuti sistematis perencanaan dan pengembangan teori dan ide untuk memecahkan masalah.

Pada fase abstract conceptualization siswa juga dilatih untuk mengidentifikasi variabel percobaan. 
Keterampilan mengidentifikasi variabel percobaan mengalami peningkatan dari pretest sebesar 1,71 menjadi 3,26 dengan gain score sebesar 0,68 dengan kategori sedang. Dalam melatihkan keterampilan mengidentifikasi variabel membutuhkan waktu yang cukup lama pada pertemuan pertama karena keterampilan tersebut sangat baru bagi siswa yang belum pernah diajarkan sebelumnya. Tetapi, setelah diberikan pelatihan melalui kegiatan eksperimen yang menuntut siswa untuk mengidentifikasi variabel, siswa sudah dapat mengidentifikasi variabel. Sesuai dengan pendapat Haynes (2007) bahwa Experiential Learning melibatkan sejumlah langkah yang memberi siswa pengalaman pembelajaran langsung, kolaboratif dan reflektif yang membantu mereka untuk sepenuhnya mempelajari keterampilan dan pengetahuan baru. Dengan kata lain, seseorang harus mengalami atau melakukan sendiri untuk memperoleh pengetahuan.

Keterampilan proses selanjutnya yaitu menginterpretasi data dan membuat kesimpulan. Sebelum itu, siswa melakukan suatu percobaan untuk menguji hipotesis yang mereka buat. Keterampilan ini masuk ke dalam fase ke empat yaitu active experimentation. Siswa melakukan percobaan berdasarkan langkah-langkah yang ada dalam LKS dan siswa akan mendapatkan data dan menuliskannya pada tabel yang telah disediakan. Siswa melakukan keterampilan proses yang selanjutnya yaitu keterampilan menginterpretasi data, yaitu siswa menemukan pola-pola dari data yang ada dengan tetap memperhatikan hipotesis yang telah meraka buat sebelumnya. Pada awal pertemuan, siswa masih kesulitan dalam membaca data dan menginterpretasikannya, masih banyak siswa dari setiap kelompok meminta bantuan guru dalam menginterpretasi data yang telah didapatkan. Tetapi, untuk pertemuan selanjutnya siswa sudah mulai paham dan mengerti dengan bantuan percobaan dan memberikan contoh-contoh yang terkait. Keterampilan menginterpretasi data setelah diterapkan model experiential Learning mengalami peningkatan dari pretest sebesar 2,11 menjadi 0,74 dengan gain score 0,74 dengan kategori tinggi. Setelah data di analisis, keterampilan selanjutnya yaitu membuat kesimpulan. Keterampilan membuat kesimpulan mengalami peningkatan dari pretest 2,08 menjadi 3,55 dengan gain score 0,77 dengan kategori tinggi. Nilai gain score membuat kesimpulan ini paling tinggi dari lima keterampilan proses sains yang diteliti. Siswa berlatih menarik kesimpulan berdasarkan data yang telah dianalisis yang disesuaikan dengan rumusan masalah yang mereka buat di awal. Latihan menyimpulkan yang ada di setiap LKS membantu siswa dalam memahami bagaimana menyimpulkan data yang tepat sesuai dengan rumusan masalah. Siswa menarik kesimpulan melalui pengalamanpengalaman belajar yang telah mereka alami selama pembelajaran berlangsung. Hal ini sesuai dengan dengan pendapat Kolb (2014) bahwa seluruh pengetahuan bersumber dari pengalaman. Sehingga melalui pengalaman ilmiah siswa dapat memperoleh pengetahuan keterampilan proses.

\section{SIMPULAN DAN SARAN}

\section{Simpulan}

Berdasarkan hasil penelitian dan pembahasan dapat disimpulkan bahwa ketuntasan keterampilan proses sains siswa secara klasikal mengalami peningkatan daripretest $5 \%$ meningkat pada posttest menjadi sebesar $92 \%$. Uji normalitas dari hasil pre-test yaitu dengan nilai Signifikansi 0,17 dan hasil uji-t berpasangan didapat nilai thitung $(13,98)<-$ ttabel $(2,247)$ sehingga dengan demikian Ho ditolak dan memiliki perbedaan yang signifikan. Dengan skor N-Gain diperoleh rata-rata peningkatan keterampilan proses sains sebesar 0,72 dengan demikian keterampilan proses sains meningkat dengan kategori tinggi. Keterampilan merumuskan masalah, menginterpretasi data, dan membuat kesimpulan mengalami peningkatan dengan kategori tinggi, sementara keterampilan membuat hipotesis dan mengidentifikasi variabel mengalami peningkatan dengan kategori sedang.

\section{Saran}

Berdasarkan penelitian yang telah peneliti lakukan dalam implementasi model guided discovery untuk meningkatkan keterampilan proses sains dapat disarankan sebagai berikut:

1. Pada penerapan model pembelajaran experiential learning maupun melatihkan keterampilan proses sains diperlukan waktu yang relatif lama terutama pada kelas VII yang masih belum terbiasa dengan kegiatan ilmiah. Oleh kareana itu untuk penelitian selanjutnya sebaiknya mengelola waktu dengan lebih baik agar pembelajaran berlangsung efektif.

2. Guru sebaiknya menyiapkan alat dan bahan yang dibutuhkan untuk percobaan sebelum pembelajaran dimulai untuk mengantisipasi apabila sekolah tidak menyediakan alat dan bahan percobaan.

\section{DAFTAR PUSTAKA}

Bundu, Patta. 2006. Penilaian Keterampilan Proses Sains dan Sikap Ilmiah dalam Pembelajaran Sains di SD. Jakarta: Depdiknas.

Hake, R. R. 1998. Interactive Engangment Methods Introductory Mechanic Course. 
Journal of Physiscs Education Research. Vol 66.

Haynes, C. (2007). Experiential learning: Learning by doing. http://adulteducation.wikibook.us/index.ph p?title=Experiential_Learning_-

_Learning_by_Doing

Kolb, D.A., 2014, Experiential Learning: Experiences as the source of Learning and Development Second Edition. Englewood Cliffs: FT Press.

Retnosari, Andarina Indah. 2015. "Implementasi Model Experiential Learning Untuk Melatihkan Keterampilan Proses Sains Siswa SMP Kelas VII Pada Materi Perpindahan Kalor". Jurnal Pendidikan Sains. Vol. 3 (2)

Rustaman, A. 2005. Pengembangan Kompetensi (Pengetahuan, keterampilan, Sikap, dan Nilai) Melalui Kegiatan Praktikum Biologi. Penelitian Jurusan Pendidikan Biologi FPMIPA UPI Bandung.
Sharlanova, V. 2004. "Experiential Learning". Department of Information and Qualification of Teacher. Vol.2 No.4, pp 3639, ISSN 1312-1723.

Sholehah, Imroatus. 2013. "Penerapan Model Experiential Learning Terhadap Hasil Belajar Fisika Siswa di SMP”. Jurnal Pendidikan Fisika. Vol. 2 No.3.

Silberman, M. 2014. Handbook Experiential Learning. Bandung: Nusa Media.

Sugiyono, Dr. 2012. Metode Penelitian Kuantitatif dan R\&D, Penerbit Alfabeta.

Suparman, Atwi. 2001. Model-model Pembelajaran Interaktif. Jakarta: STIALAN

Sukmadinata, S. 2010. Metode Penelitian Pendidikan. Bandung: Rosdakarya.

Wahono, dkk. 2014. Ilmu Pengetahuan Alam untuk SMP/MTs Kelas VII. Jakarta: Kementerian Pendidikan dan Kebudayaan. 